\title{
Salmonella sp. as the Cause of Periprosthetic Joint Infection of the Hip: Report of a Rare Case and Review of Past 10-year Literatures
}

\author{
Asep Santoso ${ }^{1,2 *}$, Pamudji Utomo ${ }^{1,2}$, Iwan Budiwan Anwar ${ }^{1,2}$, Tangkas Sibarani ${ }^{1,2}$, Bintang Soetjahjo ${ }^{1,3}$, \\ Hanif Andika Wardhana ${ }^{1}$ \\ ${ }^{1}$ Department of Orthopaedic and Traumatology, Faculty of Medicine Universitas Sebelas Maret, Solo, Indonesia; ${ }^{2}$ Department \\ of Orthopaedic and Traumatology, Prof. Dr. R. Soeharso Orthopaedic Hospital, Solo, Indonesia; ${ }^{3}$ Department of Orthopaedic \\ and Traumatology, Dr. Moewardi General Hospital, Solo, Indonesia
}

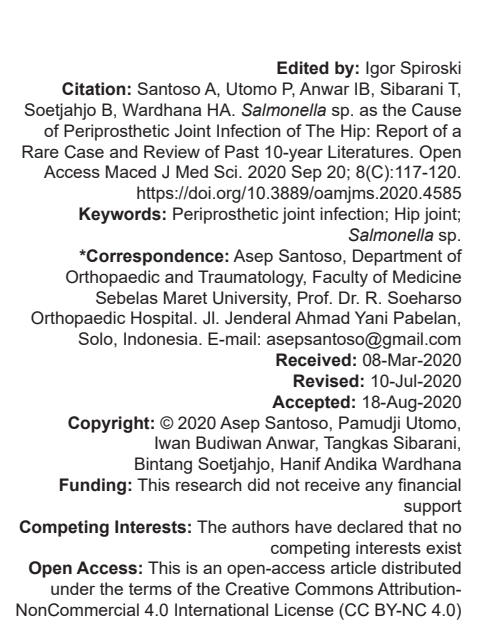

\section{Abstract}

BACKGROUND: Periprosthetic joint infection (PJI) due to Salmonella sp. is rare. It is sometimes difficult to treat and need prolonged antibiotic treatment.

CASE REPORT: We reported a case of PJI of the hip in a 67 -year-old female who received prior left total hip arthroplasty. Two-stage revision surgery with antibiotic-loaded cement spacer had been performed to the patient and successfully control the infection.

CONCLUSION: Although literature review showed that there has been no consensus for the treatment of Salmonella $\mathrm{PJI}$, a two-stage revision procedure has been more commonly performed to control the infection by previous authors and might be the safest way to control Salmonella PJI recently.

\section{Introduction}

Periprosthetic joint infection (PJI) is one of the difficult complications after joint replacement. The treatment is sometimes needed repeated surgery, which causes further morbidity to the patient. While a causative organism is most commonly Gram-positive cocci, rarely Gram-negative bacteria are also reported as isolated organism [1]. Salmonella sp. is one of the rare gram-negative causatives of organisms of periprosthetic infection after total joint replacement. We present a case of a patient with Salmonella sp. infection after total hip arthroplasty (THA) who had been treated with two-stage revision surgery.

\section{Case Presentation}

A 67-year-old female complained of pain and continuous fistula drainage on her left hip. She received
THA surgery at 6 years back due to left hip osteoarthritis. She had been able to mobilize without an assistive device. The patient began to feel pain again at her left hip since 1 year ago. Her wound was swelling and purulent material was come out. No history of fever, diarrhea, or any other illness before the recent complaint. She has no specific routine medication for any illness. History of diabetes mellitus and hypertension also denied. Physical examination showed active fistula drainage from the previous surgical wound (Figure 1a) and a limited range of hip joint movement. Serum laboratory examination showed: Hemoglobin level $10.9 \mathrm{~g} / \mathrm{dL}$, white blood count (WBC) $10.3 \times 10^{3} / \mathrm{uL}$, erythrocyte sedimentation rate / ESR-1: $73 \mathrm{~mm} / \mathrm{h}$, ESR-2: $94 \mathrm{~mm} / \mathrm{h}$, positive qualitative C-reactive protein (CRP), and blood glucose $184 \mathrm{mg} / \mathrm{dL}$. We also performed a microbiological culture and antibiotic sensitivity examination from the pus material which resulted an isolation of Salmonella sp. Pelvic radiograph examination showed a sign of loosened cemented hip prosthesis with protrusio of the acetabular component (Figure 1b). We diagnosed this patient in having a chronic PJI of the hip and planned to perform a two-stage revision procedure with the use antibiotic cement spacer. 


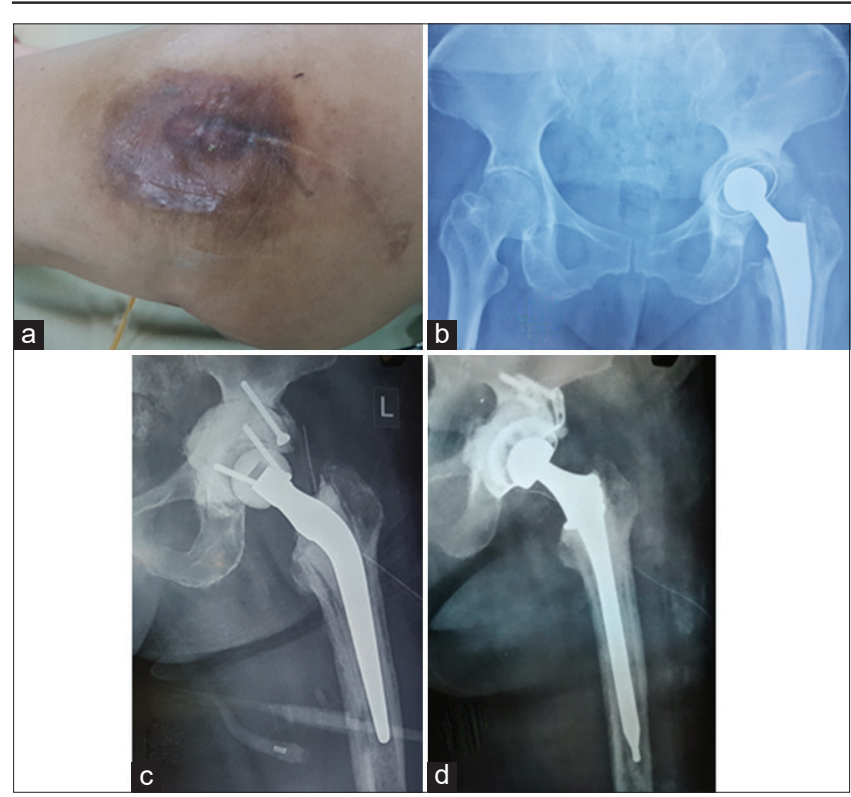

Figure 1: (a) Infected surgical wound with active pus drainage, (b) radiograph of the left infected total hip prosthesis with a sign of loosening on both femoral and acetabular components associated with acetabular protrusion. (c) Radiograph after the first-stage surgery, articulated antibiotic cement-spacer was inserted. (d) Radiograph after the second-stage revision THA

\section{Surgical procedure [1]}

The first stage of surgery consists of removal of all the prosthesis, debridement, and implantation of antibiotic-loaded cement spacer. After opening the wound and excision of wound fistula, all the purulent material and biofilm should be removed. Pus and tissue material were sent for the repetition of microbiological examination. Repeated irrigation with the use of normal saline, $10 \%$ povidone-iodine, and $3 \%$ hydrogen peroxide was then performed. Pre-sterilized femoral prostheses retrieved from previous cases were used to provide an endoskeleton for the spacers. A collar of antibioticloaded cement (1 pack, $40 \mathrm{~g}$ ) was given to the femoral component, while the acetabular components were made by inserting a bolus of cement ( 1 pack, $40 \mathrm{~g}$ ) into the acetabular cavity and molded into the shape of the cup. Screws were used as an Anchore for acetabular cement spacer to prevent cement dislodgement (Figure 1c). One gram of vancomycin (Vancep ${ }^{\circledR}$, Fahrenheit, Tangerang, Indonesia) was used on each acetabular and femoral cement spacer. Antibiotic cement Gentafixal ${ }^{\circledR}$ (Teknimed, France) impregnated with gentamicin was used for both the femoral and the acetabular component. A suction drain was used after wound closure. Regarding the result of the microbiological examination, ciprofloxacin $(200 \mathrm{mg}$ b.i.d) was given intravenously for 2 weeks followed by oral (500 mg b.i.d) for 6 weeks. Total WBC counts, ESR, and CRP were examined at 2 weekly intervals. Postoperatively, the patient was allowed to perform hip joint movement and partial weight-bearing with walker aid for mobilization.

At around 14 weeks after the first stage surgery, the surgical wound has been healed with no sign of inflammation. Laboratory examination also resulted a normal ESR level and negative of qualitative CRP. After confirming the medical fitness of the patient, the second stage revision surgery was then proceed. During the second stage of the surgery, a repeat microbiological examination was performed from tissue inside the hip joint for confirmation of the eradication state. Then, repeated wound irrigation with normal saline, 10\% povidone-iodine, and $3 \%$ hydrogen peroxide was done. We prefer to use cemented fixation for the revision THA due to a lack of bone stock (Figure 1d). A Kerboulltype acetabular cage (AK Medica, Beijing, China) was needed to address the central acetabular defect. A cemented acetabular shell (U-2 acetabular system, United, Taiwan) was used in combination with Calcarreplacement femoral prosthesis (GTF-II STEM, United, Taiwan). Antibiotic cement Gentafix ${ }^{\circledR}$ (Teknimed, France) was used both for acetabular and femoral component fixation.

Postoperatively, parenteral ciprofloxacin (200 $\mathrm{mg}$ b.i.d) was administered for 3 days followed with oral ciprofloxacin (500 mg b.i.d) for 1 week. Patients were allowed to walk with a walker as soon as the pain was tolerated. At 1 year after the second-stage surgery, a good hip functional outcome was obtained with no sign of recurrence of the infection.

\section{Discussion and literature review}

Salmonella sp. as the cause of PJI has been reported by several previous authors during the past 10-years period [2], [3], [4], [5], [6], [7], [8], [9], [10]. It can occur after total knee arthroplasty (TKA) [2], [3], [5], [6], [9], [10] or THA [4], [5], [6], [7], [8]. In a series reported by Gupta et al. [6], during 44 years study period (1969-2013) at Mayo Clinic (Rochester, USA), they only found six cases of Salmonella PJI. Five of the six cases occurred at the hip joint, with one case at the knee joint. There were several patterns of infection have been reported. Most of the authors reported a single hip or knee joint involvement of Salmonella PJI. However, a bilateral involvement of PJI of the knee also has been reported by Kobayashi et al. [2] and Rajgopal et al. [9]. de la Torre et al. [5] reported a different pattern of infection, which Salmonella PJI occurred on the knee then followed by involvement of the hip (Table 1).

Salmonella spreading is mostly hematogenous [6]. Although we did not perform blood culture, our presented case also believed to be hematogenous spreading as the onset of infection occurred at a long period (5 years) after the surgery. Direct contamination most probably suspected when the onset of infection is early ( $<4$ weeks) [7]. However, early post-operative hematogenous spreading, although unlikely, may also possible, especially for the patient with the carrier of Salmonella, which has to be proved with a fecal culture [6], [7]. The incidence of Salmonella infection increases in an immunosuppressed patient includes: 
Table 1: List of past 10 years previously reported Salmonella-PJI cases

\begin{tabular}{|c|c|c|c|c|c|c|c|c|}
\hline No & Authors & $\begin{array}{l}\text { Number of } \\
\text { cases }\end{array}$ & $\begin{array}{l}\text { Description of } \\
\text { case }\end{array}$ & Onset of infection & Bacteria & Risk factors & Treatment & Antibiotics \\
\hline 1 & $\begin{array}{l}\text { Kobayashi } \\
\text { et al. (2009) }\end{array}$ & 1 & TKA (Bilateral) & $\begin{array}{l}11 \text { years }(R) \\
6 \text { years }(L)\end{array}$ & Salmonella enterica & RA & DAIR (Both knee) & Ciprofloxacin \\
\hline 2 & $\begin{array}{l}\text { Carlile et al. } \\
(2010)\end{array}$ & 1 & TKA & 5 years & Salmonella choleraesuis & ND & Two-stage exchange & $\begin{array}{l}\text { Cefotaxime } \\
\text { Ciprofloxacin }\end{array}$ \\
\hline 3 & $\begin{array}{l}\text { Toth et al. } \\
(2010)\end{array}$ & 2 & THA & $\begin{array}{l}2 \text { years } \\
7 \text { years }\end{array}$ & $\begin{array}{l}\text { Salmonella enteritidis } \\
\text { Salmonella choleraesuis, + } \\
\text { Acinetobacter haemolyticus }\end{array}$ & $\begin{array}{l}\text { Cardiovascular } \\
\text { problems, anemia, } \\
\text { hypoalbuminemia, MOF }\end{array}$ & $\begin{array}{l}\text { One-stage exchange (1) } \\
\text { Two-stage exchange (1) }\end{array}$ & $\begin{array}{l}\text { Ciprofloxacin (2) } \\
\text { Clindamycin (1) }\end{array}$ \\
\hline 4 & $\begin{array}{l}\text { de la Torre } \\
\text { et al. (2012) }\end{array}$ & 1 & $\begin{array}{l}\text { TKA (first) } \\
\text { THA (second) }\end{array}$ & $\begin{array}{l}\text { TKA (11 month) } \\
\text { RTHA (16 years) }\end{array}$ & Salmonella enteritidis & RA & $\begin{array}{l}\text { Two-stage exchange (both } \\
\text { hip and knee) }\end{array}$ & $\begin{array}{l}\text { Ceftriaxon } \\
\text { TMP-SMX }\end{array}$ \\
\hline 5 & $\begin{array}{l}\text { Gupta et al. } \\
\text { (2014) }\end{array}$ & 6 & $\begin{array}{l}\text { TKA (1) } \\
\text { THA (5) }\end{array}$ & $\begin{array}{l}5 \text { month - } \\
9 \text { years }\end{array}$ & $\begin{array}{l}\text { Salmonella enterica (5) } \\
\text { Salmonella bongori (1) }\end{array}$ & $\begin{array}{l}\text { DM, RA, CKD, Bladder } \\
\text { Ca, Colitis Ulcerative, } \\
\text { Skin Ca, Colonic Polyp }\end{array}$ & $\begin{array}{l}\text { Two-stage exchange (4) } \\
\text { Removal + Debridement + } \\
\text { arthrodesis (2) }\end{array}$ & $\begin{array}{l}\text { Ceftriaxon (2) } \\
\text { Ampicillin (2) } \\
\text { Ciprofloxacin (2) } \\
\text { TMP-SMX (1) } \\
\text { Amoxycillin (1) }\end{array}$ \\
\hline 6 & $\begin{array}{l}\text { Jeroense et } \\
\text { al. }(2014)\end{array}$ & 2 & THA & $\begin{array}{l}7 \text { days } \\
13 \text { years }\end{array}$ & $\begin{array}{l}\text { Salmonella type } \mathrm{E} \\
\text { Salmonella enteritidis }\end{array}$ & $\begin{array}{l}\text { CKD, Carcinoid tumor of } \\
\text { lung, Adenoma pituitary }\end{array}$ & $\begin{array}{l}\text { One-stage exchange + } \\
\text { DAIR (1) } \\
\text { One-stage exchange }\end{array}$ & $\begin{array}{l}\text { Vancomycin (1) } \\
\text { Ciprofloxacin (2) }\end{array}$ \\
\hline 7 & $\begin{array}{l}\text { Ekinci et al. } \\
(2017)\end{array}$ & 2 & THA & $\begin{array}{l}1 \text { years } \\
6 \text { years }\end{array}$ & $\begin{array}{l}\text { Salmonella typhimurium } \\
\text { Salmonella type C }\end{array}$ & $\begin{array}{l}\text { Azathioprine and } \\
\text { Prednisolone Induced- } \\
\text { immunocompromised }\end{array}$ & Two-stage exchange (2) & $\begin{array}{l}\text { Cefazolin (1) } \\
\text { Ciprofloxacin (2) }\end{array}$ \\
\hline 8 & $\begin{array}{l}\text { Rajgopal } \\
\text { et al. (2017) }\end{array}$ & 1 & TKA (Bilateral) & 10 months & Salmonella Typhi & DM, RA & Two-stage exchange & ND \\
\hline 9 & $\begin{array}{l}\text { Sebastian } \\
\text { et al. (2017) }\end{array}$ & 1 & TKA & 4 years & Salmonella typhimurium & $\begin{array}{l}\text { Tubercular meningitis, } \\
\text { DM }\end{array}$ & Two-stage exchange & $\begin{array}{l}\text { Cefuroxime } \\
\text { Levofloxacin }\end{array}$ \\
\hline 10 & $\begin{array}{l}\text { Present } \\
\text { report }\end{array}$ & 1 & THA & 5 years & Salmonella sp. & Hyperglycemia & Two-stage exchange & $\begin{array}{l}\text { Gentamycin + Vancomycin } \\
\text { (spacer) } \\
\text { Ciprofloxacin }\end{array}$ \\
\hline
\end{tabular}

Rheumatoid arthritis, malignancy, diabetes mellitus, chronic kidney disease, a prolonged steroid medication, and history of gastrointestinal system disease [6], [7], [8]. In our recent case, although the patient denied any history of diabetes mellitus, blood glucose examination revealed a high glucose level. Therefore, an immunosuppressed state also maybe occurs to our patient.

There is no consensus in the treatment of periprosthetic Salmonella infections. Kobayashi et al. [2] successfully control chronic Salmonella PJI by performing debridement and implant retention to bilateral TKA. de la Torre et al. [5] reported that two-stage revision is the best choice of treatment, conservative treatment with antibiotics alone is insufficient to control the infection. Gupta et al. [6] also reported four of six patients which treated with antibiotics alone or combined with debridement and implant retention were failed and needed implant removal to control the infection. The two-stage revision also has been successfully control the infection in cases reported by other authors [3], [8], [9], [10]. However, another report by Jeroense et al. [7] showed that one-stage revision also could be successful for the treatment of Salmonella PJI when the onset is acute.

Antibiotic is one of the most important parts of the treatment. In our recent case, we found that the Salmonella sp. is sensitive to amikacin, gentamicin, fosfomycin, imipenem, meropenem, ciprofloxacin, and levofloxacin. Similar to our reported case, ciprofloxacin was used as the antibiotic treatment by most previous authors [2], [3], [4], [6], [7], [8]. Gupta et al. [6] use ceftriaxon, ampicillin, trimetoprim-sulfametoxazol, and ciprofloxacin to treat their patients. Several previous authors also use cephalosporin antibiotics as the treatment choice for their cases [3], [5], [6], [9], [10]. In our case, it has been found that the Salmonella sp. was resistant to most of the cephalosporin antibiotics include ceftriaxon, cefotaxime, cefixime, and cefadroxil, also for ampicillin-sulbactam and trimetoprim-sulfametoxazol. It is showed that the pattern of Salmonella antibiotic sensitivity might be different or has been changed by time. In summary, Salmonella infections are rarely seen after hip arthroplasty. Although literature review showed that there has been no consensus for the treatment of Salmonella PJI, two-stage revision procedure has been more commonly performed to control the infection by previous authors and might be the safest way to control Salmonella PJI recently.

\section{References}

1. Santoso A, Park KS, Shin YR, Yang HY, Choi IS, Yoon TR Two-stage revision for periprosthetic joint infection of the hip: Culture-negative versus culture-positive infection. J Orthop. 2018;15(2):391-5. https://doi.org/10.1016/j.jor.2018.03.002 PMid:29881161

2. Kobayashi H, Hall GS, Tuohy MJ, Knothe U, Procop GW, Bauer TW. Bilateral periprosthetic joint infection caused by Salmonella enterica serotype enteritidis, and identification of Salmonella sp using molecular techniques. Int J Infect Dis. 2009;13(6):e463-6. https://doi.org/10.1016/j.ijid.2008.12.015 PMid:19269872

3. Carlile GS, Elvy J, Toms AD. Salmonella infection of a total knee replacement. Knee. 2010;17(5):356-8. https://doi.org/10.1016/j. knee.2009.10.003

4. Tóth K, Janositz G, Kovács G, Sisák K, Rudner E. Successfu treatment of late Salmonella infections in total hip replacementreport of two cases. BMC Infect Dis. 2010;10:160. https://doi. org/10.1186/1471-2334-10-160 PMid:20529326

5. de la Torre B, Tena D, Arias M, Romanillos O. Recurrent prosthetic joint infection due to Salmonella Enteritidis: Case report and 
literature review. Eur J Orthop Surg Traumatol. 2012;22 Suppl 1:89-97. https://doi.org/10.1007/s00590-012-0955-6

PMid:26662756

6. Gupta A, Berbari EF, Osmon DR, Virk A. Prosthetic joint infection due to Salmonella species: A case series. BMC Infect Dis. 2014;14:633. https://doi.org/10.1186/s12879-014-0633-x PMid:25424009

7. Jeroense KT, Kuiper JW, Colen S, Schade RP, Saouti R. One-stage revision in two cases of Salmonella prosthetic hip infection. World J Clin Cases. 2014;2(7):304-8.

PMid:25032209

8. Ekinci M, Bahyram S, Akgul T, Ersin M, Yazicioglu Ö. Periprostetic joint infection caused by Salmonella: Case reports of two azathioprine and prednisolone induced-immunocompromised patients. Hip Pelvis. 2017;29(2):139-44 https://doi.org/10.5371/ hp.2017.29.2.139

PMid:28611966

9. Rajgopal A, Panda I, Gupta A. Unusual Salmonella typhi periprosthetic joint infection involving bilateral knees: Management options and literature review. BMJ Case Rep. 2017;2017:bcr2017221221. https://doi.org/10.1136/ bcr-2017-221221

PMid:29141925

10. Sebastian S, Dhawan B, Malhotra R, Gautam D, Kapil A. Salmonella typhimurium infection in total knee arthroplasty: A case report with review of literature. J Lab Physicians. 2017;9(3):217-9. https://doi.org/10.4103/0974-2727.208254 PMid:28706395 